\title{
Ensifer, Phyllobacterium and Rhizobium species occupy nodules of Medicago sativa (alfalfa) and Melilotus alba (sweet clover) grown at a Canadian site without a history of cultivation
}

Correspondence

E. S. P. Bromfield

eden.bromfield@agr.gc.ca

Received 27 August 2009

Revised 20 October 2009

Accepted 24 October 2009

\author{
E. S. P. Bromfield, ${ }^{1}$ J. T. Tambong, ${ }^{1}$ S. Cloutier, ${ }^{1}$ D. Prévost, $^{2}$ G. Laguerre, ${ }^{3}$ \\ P. van Berkum, ${ }^{4}$ T. V. Tran Thi, ${ }^{1}$ R. Assabgui ${ }^{1}$ and L. R. Barran ${ }^{1}$ \\ ${ }^{1}$ Agriculture and Agri-Food Canada, Ottawa, Ontario K1A OC6, Canada \\ ${ }^{2}$ Agriculture and Agri-Food Canada, 2560 Hochelaga Blvd, Quebec G1V 2J3, Canada \\ ${ }^{3}$ INRA, USC 1242 Symbioses Tropicales et Méditerranéennes, F-34398 Montpellier, France \\ ${ }^{4}$ USDA ARS, Bldg 006, BARC-West, 10300 Baltimore Ave, Beltsville, MD 20705, USA
}

\begin{abstract}
Phage-resistant and -susceptible bacteria from nodules of alfalfa and sweet clover, grown at a site without a known history of cultivation, were identified as diverse genotypes of Ensifer, Rhizobium and Phyllobacterium species based on sequence analysis of ribosomal (16S and 23S rRNA) and protein-encoding ( $a t p D$ and $r e c A$ ) genes, Southern hybridization/RFLP and a range of phenotypic characteristics. Among phage-resistant bacteria, one genotype of Rhizobium sp. predominated on alfalfa (frequency $\sim 68 \%$ ) but was recovered infrequently $(\sim 1 \%)$ from sweet clover. A second genotype was isolated infrequently only from alfalfa. These genotypes fixed nitrogen poorly in association with sweet clover and Phaseolus vulgaris, but were moderately effective with alfalfa. They produced a near-neutral reaction on mineral salts agar containing mannitol, which is atypical of the genus Rhizobium. A single isolate of Ensifer sp. and two of Phyllobacterium sp. were recovered only from sweet clover. All were highly resistant to multiple antibiotics. Phylogenetic analysis indicated that Ensifer sp. strain T173 is closely related to, but separate from, the non-symbiotic species 'Sinorhizobium morelense'. Strain T173 is unique in that it possesses a $175 \mathrm{~kb}$ symbiotic plasmid and elicits ineffective nodules on alfalfa, sweet clover, Medicago lupulina and Macroptilium atropurpureum. The two Phyllobacterium spp. were non-symbiotic and probably represent bacterial opportunists. Three genotypes of $E$. melilot $i$ that were symbiotically effective with alfalfa and sweet clover were encountered infrequently. Among phage-susceptible isolates, two genotypes of $E$. medicae were encountered infrequently and were highly effective with alfalfa, sweet clover and Medicago polymorpha. The ecological and practical implications of the findings are discussed.
\end{abstract}

\section{INTRODUCTION}

Rhizobia are soil bacteria of considerable economic importance. In symbiotic association with legume crops they have the potential to fix nitrogen in amounts sufficient to reduce the dependency of agriculture on nitrogen fertilizers. Populations of rhizobia represent a valuable bioresource that may be exploited via selection of bacteria with desirable traits for use in inoculants intended to maximize legume crop productivity. Information on the diversity, dynamics and characteristics of populations of rhizobia residing in soil is therefore of considerable practical importance.

Abbreviations: PT, phage type; RE, relative effectiveness.

Supplementary material is available with the online version of this paper.
Studies on the diversity of rhizobia often depend on the analysis of 16S rRNA gene sequences for species-level identification. However, several studies have shown that 16S rRNA genes may undergo recombination and horizontal transfer resulting in sequence mosaicism (e.g. van Berkum et al., 2003; Vinuesa et al., 2005). Another disadvantage of bacterial identification based on the analysis of $16 \mathrm{~S}$ rRNA genes is that closely related species cannot always be differentiated because of high levels of sequence conservation (Martens et al., 2007). To surmount these difficulties, the use of other genes such as proteinencoding (housekeeping) genes with greater sequence divergence than 16S rRNA genes, but sufficiently conserved to be phylogenetically useful, are recommended as supplementary genetic markers for identification of the rhizobia (e.g. Martens et al., 2007, 2008). 
Medicago sativa (alfalfa) and Melilotus alba (sweet clover) are forage legumes that fix nitrogen in symbiotic association with the bacterial species Ensifer meliloti. Bromfield et al. (2001), characterized 1620 bacterial isolates from nodules of alfalfa and sweet clover) grown for two seasons at a Canadian site (latitude $45^{\circ} 23^{\prime} 6.28^{\prime \prime} \mathrm{N}$; longitude $75^{\circ} 42^{\prime} 15.65^{\prime \prime} \mathrm{W}$ ) without a known history of cultivation. Initially, bacteria able to nodulate alfalfa and sweet clover were not detected in soil, whereas in the second season their numbers increased markedly, presumably in response to the presence of legumes. Based on the use of 16 E. meliloti typing phages, a wide array of phage sensitivity patterns (phage types; PTs) were encountered among bacterial isolates sampled from both plant species. Phage-resistant isolates, designated PT14, from nodules of alfalfa were unusual in that they were predominant, whereas from sweet clover they were encountered infrequently. Based on nod gene hybridization patterns, the PT14 isolates from alfalfa were relatively homogeneous while those from sweet clover were heterogeneous.

Our aim was to obtain information on the species diversity and phenotypic characteristics of these unusual phageresistant bacterial isolates from root nodules of alfalfa and sweet clover. This was accomplished by Southern hybrid- ization using a variety of insertion sequence (IS) and symbiotic gene probes, by sequence analysis of ribosomal (16S and $23 \mathrm{~S}$ rRNA) and protein-encoding ( $a t p D$ and recA) genes, as well as a range of phenotypic determinations including plasmid profiles, resistance to antibiotics, symbiotic effectiveness and host range of nodulation. We also characterized phage-susceptible isolates belonging to PTs 13 and 24 that had unusual colony morphology relative to $E$. meliloti reference strains. A final objective was to estimate the frequency of genotypes and species among bacterial isolates comprising phage-resistant and -susceptible types.

\section{METHODS}

Bacteria. Single-colony isolates of bacteria from nodules of alfalfa and sweet clover were maintained at $-80{ }^{\circ} \mathrm{C}$ in $20 \%(\mathrm{v} / \mathrm{v})$ glycerol. In the earlier work (Bromfield et al., 2001), a subsample consisting of 180 of 561 phage-resistant isolates (PT14) from alfalfa and all 19 PT14 isolates from sweet clover were placed in a number of distinct groups based on nodEFG hybridization. Bacterial isolates representative of each of these groups as well as several isolates randomly selected from those belonging to each of PTs 13 and 24 (susceptible to eight and one of 16 typing phages, respectively) were used for further characterization in this study. Reference strains and representative examples of the bacterial isolates studied are shown in Table 1 .

Table 1. Reference strains and representative bacteria used in this study

Superscript $\mathrm{T}$ designates type strains.

\begin{tabular}{|c|c|c|c|}
\hline Strain & Origin & Host plant & Source or reference \\
\hline \multicolumn{4}{|l|}{ E. meliloti } \\
\hline ATCC $9930^{\mathrm{T}}$ & USA & Med. sativa & ATCC, USA \\
\hline SU47 & Australia & Med. sativa & Rothamsted, UK \\
\hline T15 & Canada & Med. sativa & This study \\
\hline T1580 & Canada & Mel. alba & This study \\
\hline T1607 & Canada & Mel. alba & This study \\
\hline \multicolumn{4}{|l|}{ E. medicae } \\
\hline M102 & Syria & Med. trunculata & Eardly et al. (1990) \\
\hline $\mathrm{T} 2$ & Canada & Mel. alba & This study \\
\hline T10 & Canada & Med. sativa & This study \\
\hline \multicolumn{4}{|l|}{ Ensifer sp. } \\
\hline $\mathrm{T} 173$ & Canada & Mel. alba & This study \\
\hline \multicolumn{4}{|l|}{ 'Sinorhizobium morelense' } \\
\hline $\mathrm{LC}^{\mathrm{T}}{ }^{\mathrm{T}}$ & Mexico & Leucaena leucocephala & Wang et al. (2002) \\
\hline \multicolumn{4}{|l|}{ Rhizobium sp. } \\
\hline OR191 & USA & Med. sativa & Eardly et al. (1992) \\
\hline T1470 & Canada & Med. sativa & This study \\
\hline T1473 & Canada & Med. sativa & This study \\
\hline T136 & Canada & Mel. alba & This study \\
\hline T1155 & Canada & Med. sativa & This study \\
\hline \multicolumn{4}{|l|}{ Phyllobacterium sp. } \\
\hline T1018 & Canada & Mel. alba & This study \\
\hline T1293 & Canada & Mel. alba & This study \\
\hline \multicolumn{4}{|l|}{ R. etli } \\
\hline $\mathrm{CFN} 42^{\mathrm{T}}$ & Mexico & Phaseolus vulgaris & Segovia et al. (1993) \\
\hline \multicolumn{4}{|l|}{ R. radiobacter } \\
\hline PD67 (synthetic derivative of C58) & & & Bromfield et al. (1987) \\
\hline
\end{tabular}


Table 2. DNA probes

\begin{tabular}{|c|c|c|c|}
\hline $\begin{array}{l}\text { Insertion sequence } \\
\text { or symbiotic gene }\end{array}$ & Plasmid & Probe characteristics & Reference \\
\hline ISRm1 & pRWRm13 & $0.9 \mathrm{~kb} B g l \mathrm{I}-E c o \mathrm{RV}$ internal ISRm 1 fragment & Barran et al. (1991) \\
\hline ISRm3 & pRWRm31 & $1.3 \mathrm{~kb} E c o$ RI internal ISRm3 fragment & Barran et al. (1994) \\
\hline ISRm5 & pRWRm61 & $0.8 \mathrm{~kb} B s t \mathrm{XI}-\mathrm{XhoI}$ internal ISRm 5 fragment & Barran et al. (1994) \\
\hline nodC & pVR3 & 177 bp RsaI internal nodC fragment & Rastogi et al. (1992) \\
\hline nodH & pSW95 & $0.3 \mathrm{~kb}$ BamHI-PstI nodH fragment & Bromfield et al. (1994) \\
\hline nodEFG & pEK10 & $7 \mathrm{~kb}$ EcoRI nodEFG fragment & Bromfield et al. (2001) \\
\hline nifH & pVR6 & $1.23 \mathrm{~kb}$ HindIII-BglII nifH fragment & Rastogi et al. (1992) \\
\hline
\end{tabular}

RFLP and Southern hybridization. The DNA probes Is $R m 1$, Is Rm3, IsRm5, nodEFG, nodH, nodC and nifH were used for Southern hybridization (Table 2). Genomic DNAs were extracted and purified using the Wizard SV Genomic DNA Purification System (Promega) according to the manufacturer's protocol; DNA concentration was determined using a NanoDrop ND-1000 spectrophotometer. Genomic DNAs were digested to completion with EcoRI, BamHI or Sall. The resulting DNA fragments were separated by gel electro- phoresis, blotted onto nitrocellulose and hybridized to the respective ${ }^{32}$ P-labelled DNA probes (Barran et al., 1994).

Nucleotide sequencing. Full-length $16 \mathrm{~S}$ rRNA and partial $23 \mathrm{~S}$ rRNA, atpD and recA genes were amplified by PCR for subsequent DNA sequence analysis. Primers used for amplification and sequencing as well as temperature and PCR cycling conditions are shown in Table 3. Primers were derived from the literature except for $23 \mathrm{~S} 3 \mathrm{f}$ and

Table 3. Oligonucleotide primers

Primers in bold were used for PCR amplification as well as sequencing; remaining primers were used only for sequencing.

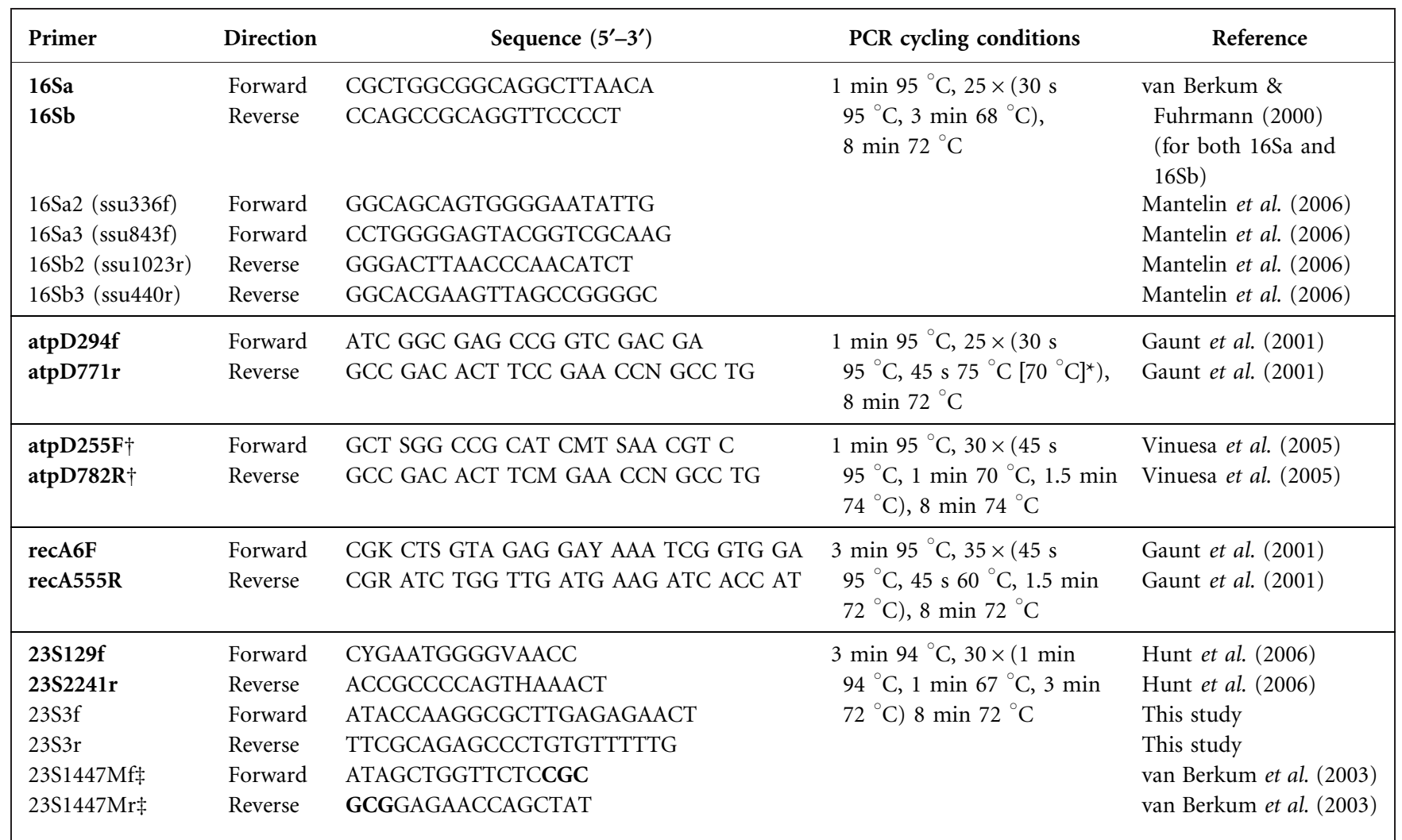

${ }^{\star}$ S. morelense $\mathrm{LC} 04^{\mathrm{T}}$ and Rhizobium sp. strains T136, T1470, T1155, T1473 and OR191 amplified only at $70{ }^{\circ} \mathrm{C}$ annealing temperature. $\dagger$ Primers used only for strains T173 (Ensifer sp.) and T1018 (Phyllobacterium sp.).

$\$$ Primers modified at the locations shown in bold. 
23S3r, which were determined by analysis of partial sequences using the software Primer Select (DNASTAR Lasergene 7). Primer locations for $23 \mathrm{~S} 3 \mathrm{f}$ and $23 \mathrm{~S} 3 \mathrm{r}$ were $1633-1655$ and $1784-1763$, respectively, relative to the 23S rRNA sequence in the complete genome of $E$. meliloti 1021 (GenBank accession no. NC003047).

The volumes of PCRs were $50 \mu \mathrm{l}$, containing 50-75 ng DNA, $0.15 \mathrm{mM}$ each dNTP, $1.0 \mu \mathrm{M}$ each primer, $1 \times$ Titanium Taq DNA polymerase (Clontech Laboratories) and $1 \times$ buffer that was supplied with the enzyme. An Eppendorf Mastercycler Gradient PCR was used to carry out amplifications. Subsequently, $1 \mu \mathrm{l}$ of the PCR products was examined by electrophoresis in $1 \%$ agarose gels containing ethidium bromide, using a marker ladder as reference. PCR products with a clean single band of the correct molecular size were purified by using Montage PCR Centrifugal Filter Devices (Millipore). For products with multiple bands, the bands with the expected size were excised from the gel and purified using QIAEX II DNA gel extraction kit (Qiagen). Purified PCR products were sequenced using ABI BigDye Terminator chemistry v3.0 (Applied Biosystems) as described by Tambong et al. (2006) and analysed on an ABI 3100-Avant automated sequencer (Applied Biosytems/Hitachi).

Phylogenetic analysis. Nucleotide sequences of $16 \mathrm{~S}$ rRNA, 23S rRNA, atpD and recA genes were edited using SEQMAN (DNASTAR, v.7.0) and multiple alignments for each set of sequences were done using CLUSTAL W as implemented in MEGALIGN. Nucleotide sequences for type strains of relevant taxa were obtained from GenBank and included in the analyses. For reference purposes we sequenced the16S rRNA, 23S rRNA, atpD and recA genes of 'Sinorhizobium morelense' strain $\mathrm{Lc} 4^{\mathrm{T}}$ (obtained from E. Martinez-Romero, UNAM, Mexico) as well as the non-type strains Ensifer medicae M102 (Eardly et al., 1990) and Rhizobium sp. OR191 (Eardly et al., 1992).

Molecular phylogenies were estimated using MEGA4 (Tamura et al., 2007). The model for each set of sequences was selected on the basis of the Akaike information criterion implemented in Model Test 3.7 (Posada, 2006). Evolutionary histories were inferred using the neighbour-joining method (Saitou \& Nei, 1987) and bootstrap consensus trees inferred from 1000 permutations of the datasets (Felsenstein, 1985). Evolutionary distances were computed using the Tamura-Nei method (Tamura \& Nei, 1993) as the number of base substitutions per site. The rate variation among sites was modelled with a gamma distribution. All positions containing gaps and missing data were eliminated from each dataset (complete deletion option).

Nucleotide sequences generated in this study were deposited in GenBank and their accession numbers are shown in the phylogenetic trees.

The name Ensifer was used to designate bacterial species comprising the former genus Sinorhizobium with the exception of 'S. morelense', which retains its nomenclature (Young, 2003; Martens et al., 2007, 2008).

Frequency. Frequency estimates for bacterial genotypes were based on the phage type data of Bromfield et al. (2001), where 810 bacterial isolates is the total sample size from alfalfa and sweet clover, respectively. Frequencies of bacterial genotypes among phageresistant isolates (PT14) were estimated by combining the nodEFG hybridization data of Bromfield et al. (2001) with those obtained by RFLP/Southern hybridization in this study. The frequencies of genotypes among PT14 isolates from alfalfa $(A)$ were based on a subsample of 180 from 561 isolates and estimated from [(xA14/180) $(561 / 810)] \times 100$, where $x A 14$ is the number of PT14 isolates in the subsample of 180 belonging to a particular nodEFG type and 561/810 represents the proportion of isolates belonging to PT14 in the total sample from alfalfa.

Frequency estimates of genotypes for phage-susceptible isolates (PTs 13 and 24) were based on the assumption that phage type and genotype (defined by Southern hybridization) are correlated as demonstrated by Barran et al. (1994).

Plasmids. Analysis of plasmid content was done by horizontal agarose gel electrophoresis as described by Bromfield et al. (1987). Blotting, labelling $\left({ }^{32} \mathrm{P}\right)$ and hybridization with DNA probes for nifH and nodC genes was as described by Barran et al. (1994). Estimates of the molecular size of bacterial plasmids were made by reference to standard plasmids of 410,270, 180 and $55 \mathrm{~kb}$ in Rhizobium radiobacter PD67 (Bromfield et al., 1987). The megaplasmid band of E. meliloti SU47, consisting of pSymA $(\sim 1300 \mathrm{~kb})$ and $\mathrm{pSymB}$ $(\sim 1700 \mathrm{~kb})$ (Barnett et al., 2001), was used as a standard to detect plasmids of equivalent mobility.

Antibiotic resistance and acid production. Assays of intrinsic antibiotic resistance were done on tryptone yeast-extract (TY) agar medium (Bromfield et al., 1994) amended with filter-sterilized solutions of the following antibiotics (Sigma Aldrich) at the following final concentrations $\left.(\mu \mathrm{g} \mathrm{ml})^{-1}\right)$ : carbenicillin, 5, 50, 100, 1000; kanamycin, 5, 50, 100, 500; erythromycin and neomycin sulphate, $5,50,100,300$; gentamicin sulphate and tetracycline hydrochloride, 5, 50; nalidixic acid, 5, 20). Inoculation was by a multiple inoculator that simultaneously delivered 16 samples $(\sim 2 \mu \mathrm{l})$ to each plate. The inoculum for each bacterial strain, suspended in water, was

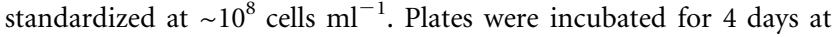
$28{ }^{\circ} \mathrm{C}$ and bacterial growth recorded from duplicate plates of each antibiotic concentration.

Acid-production (final $\mathrm{pH}$ ) assays were carried out using slopes of modified yeast-extract mannitol (YEM) agar medium (Bromfield et al., 1994), inoculated with $0.1 \mathrm{ml}$ washed bacterial cell suspension $\left(\sim 10^{8}\right.$ cells $\left.\mathrm{ml}^{-1}\right)$. Bromothymol blue $(0.0025 \%)$ was added to the growth medium as $\mathrm{pH}$ indicator. The $\mathrm{pH}$ of the agar medium (five replicates per bacterial culture) was recorded after 21 days at $28{ }^{\circ} \mathrm{C}$.

Plant tests. Seedlings from surface-sterilized seed were inoculated with washed bacterial culture $\left(\sim 10^{8}\right.$ cells $)$ and grown axenically in plant growth pouches (Mega International), in glass tubes $(30 \times 200 \mathrm{~mm})$ containing vermiculite or in Leonard jar assemblies containing sand/grit mixture supplied with nitrogen-free nutrient solution as described by Bromfield et al. (1987). Plants were grown in controlled-environment cabinets for 35 days at $\sim 250 \mu \mathrm{E} \mathrm{m} \mathrm{m}^{-2} \mathrm{~s}^{-1}$ (16 h light, $25^{\circ} \mathrm{C} ; 8 \mathrm{~h}$ dark, $16{ }^{\circ} \mathrm{C}$ ). Significance in variation of symbiotic characteristics was determined by analysis of variance (GENSTAT, Release 8.1).

The relative effectiveness (RE) with regard to nitrogen fixation of bacterial strains was calculated as $\left[\left(x-x^{\mathrm{o}}\right) /\left(x^{\mathrm{e}}-x^{\mathrm{o}}\right)\right] \times 100$ where $x, x^{\mathrm{o}}$ and $x^{\mathrm{e}}$ designate the mean shoot dry weights of, respectively, plants inoculated with a given bacterial strain, uninoculated plants and plants inoculated with a symbiotically effective standard strain.

RE values were derived from means of five (Medicago sativa, Melilotus alba and Phaseolus vulgaris) and nine (Medicago polymorpha) replicates (two plants per replicate) for each inoculation treatment and host plant combination.

\section{RESULTS}

\section{RFLP and Southern hybridization}

Data for Southern hybridization patterns of genomic DNAs from bacterial strains representative of phage-resistant and -susceptible types and nodEFG hybridization groups (Bromfield et al., 2001) are shown in Table 4. Hybridization profiles generated using DNA probes for 
Table 4. Estimated frequency of bacteria from nodules of Med. sativa and Mel. alba and characterization by insertion sequence (IS) and nod gene hybridization Genomic DNAs were digested with EcoRI (ISRm1), BamHI (ISRm3, ISRm5, nodH) or SalI (nodEFG). Values in parentheses (PTs 13 and 24) represent the number of isolates characterized by Southern hybridization in this study.

\begin{tabular}{|c|c|c|c|c|c|c|c|c|c|c|c|c|}
\hline \multirow{2}{*}{$\begin{array}{l}\text { Representative } \\
\text { bacterial strain }\end{array}$} & \multicolumn{5}{|c|}{ No. of hybridizing bands with DNA probe ${ }^{\star}$} & \multirow[t]{2}{*}{ IS/nod genotype } & \multirow[t]{2}{*}{ Identification $\dagger$} & \multirow[t]{2}{*}{ Phage type $\ddagger$} & \multicolumn{2}{|c|}{ Med. sativa $\ddagger$} & \multicolumn{2}{|c|}{ Mel. alba $\ddagger$} \\
\hline & nodEFG & nodH & ISRm 1 & ISRm3 & ISRm5 & & & & No. isolates & Frequency & No. isolates & Frequency \\
\hline \multicolumn{13}{|l|}{$\begin{array}{l}\text { Phage-resistant } \\
\text { strains }\end{array}$} \\
\hline T15 & 4 & $1 \mathrm{a}$ & 1 & 8 & 5 & $\mathrm{~F}$ & E. meliloti & 14 & 1 & 0.38 & 0 & \\
\hline T1580 & 2 & $1 \mathrm{a}$ & 0 & 3 & 6 & G & E. meliloti & 14 & 0 & & 6 & 0.74 \\
\hline T1607 & 6 & $1 \mathrm{~b}$ & 2 & 4 & 7 & $\mathrm{H}$ & E. meliloti & 14 & 0 & & 2 & 0.25 \\
\hline T173 & 7 & $1 \mathrm{~b}$ & 0 & 1 & 0 & $\mathrm{C}$ & Ensifer sp. & 14 & 0 & & 1 & 0.12 \\
\hline T1470, T1473 & 3 & $1 \mathrm{c}$ & 0 & 1 & 0 & A & Rhizobium sp. & 14 & 3 & 1.15 & 0 & \\
\hline T136, T1155 & $2 \mathrm{a}$ & $1 \mathrm{c}$ & 0 & 0 & 0 & B & Rhizobium sp. & 14 & 176 & 67.72 & 8 & 0.99 \\
\hline T1018 & 0 & 0 & 0 & 0 & 0 & I & Phyllobacterium sp. & 14 & 0 & & 1 & 0.12 \\
\hline $\mathrm{T} 1293$ & 0 & 0 & 0 & 0 & 0 & I & Phyllobacterium sp. & 14 & 0 & & 1 & 0.12 \\
\hline \multicolumn{13}{|l|}{$\begin{array}{l}\text { Phage-susceptible } \\
\text { strains }\end{array}$} \\
\hline $\mathrm{T} 2$ & 9 & $1 \mathrm{~d}$ & 2 & 5 & 5 & $\mathrm{D}$ & E. medicae & 24 & $10(2)$ & 1.23 & $57(4)$ & 7.04 \\
\hline T10 & 9 & 1 & 2 & 6 & 2 & $\mathrm{E}$ & E. medicae & 13 & $3(2)$ & 0.37 & $9(3)$ & 1.11 \\
\hline \multicolumn{13}{|l|}{ Reference strains } \\
\hline $\begin{array}{l}\text { E. meliloti ATCC } \\
9930^{\mathrm{T}}\end{array}$ & 6 & $1 \mathrm{~b}$ & 1 & 5 & 5 & $\mathrm{~J}$ & & & & & & \\
\hline $\begin{array}{l}\text { Rhizobium sp. } \\
\text { OR191 }\end{array}$ & $2 \mathrm{a}$ & $1 \mathrm{c}$ & 0 & 0 & 0 & B & & & & & & \\
\hline E. medicae M102 & 9 & $1 \mathrm{~d}$ & 1 & 3 & 0 & $\mathrm{~K}$ & & & & & & \\
\hline $\begin{array}{l}\text { No. of hybridiza- } \\
\text { tion profiles }\end{array}$ & 11 & 6 & 7 & 10 & 7 & & & & & & & \\
\hline
\end{tabular}

${ }^{*}$ Identical hybridization profiles for a particular DNA probe are indicated by a common letter.

$\dagger$ Identification based on analyses of $16 \mathrm{~S}$ rRNA, 23S rRNA, atpD and recA gene sequences.

¥Phage type and frequency data based on Bromfield et al. (2001); PT14 isolates from Med. sativa represent a subsample of 180 from 561 isolates. 


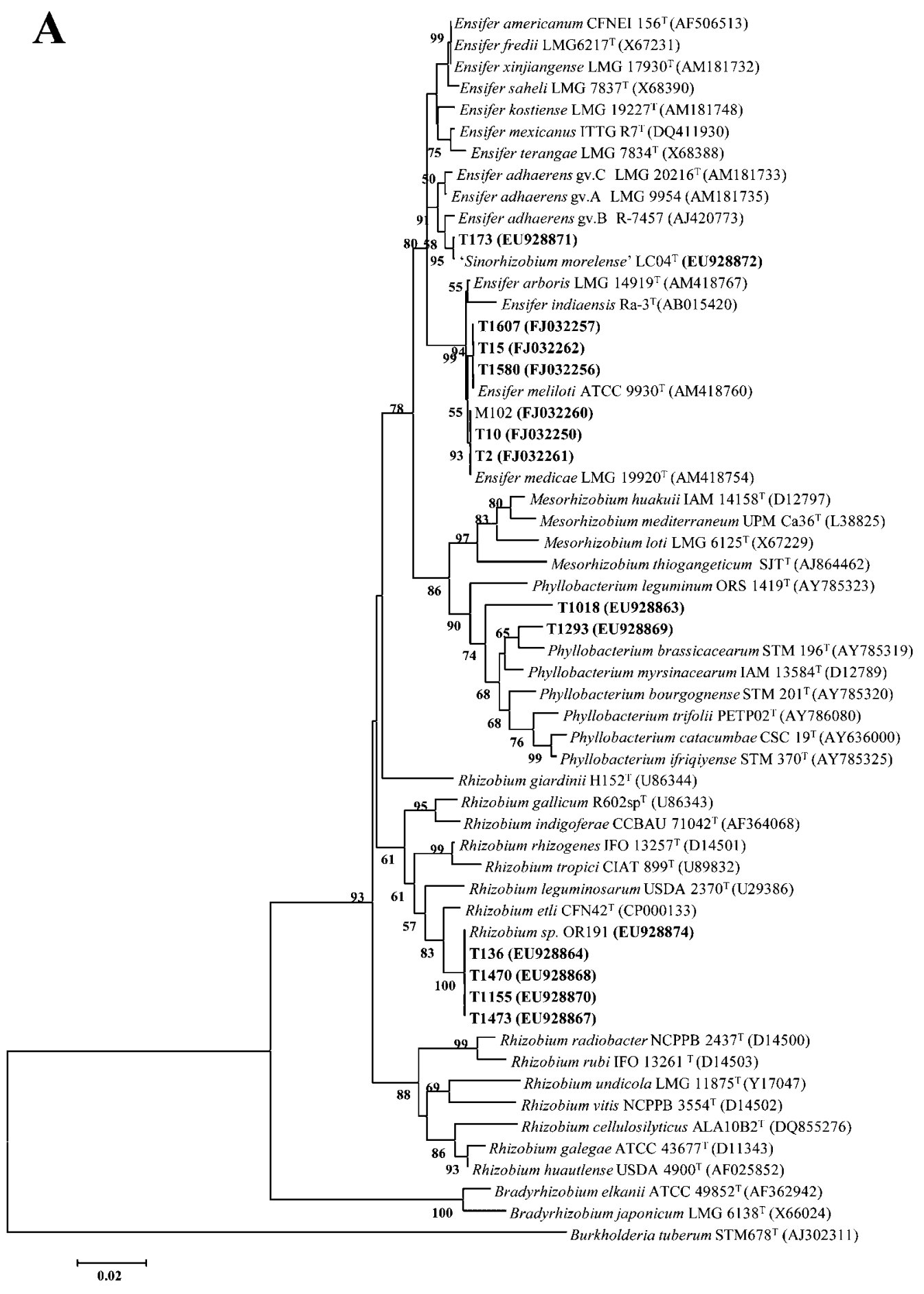

Fig. 1 (continues on following pages). Neighbour-joining bootstrap consensus trees based on sequences of 16S rRNA (A), 23S rRNA $(\mathrm{B}), \operatorname{rec} A(\mathrm{C})$ and $a t p D(\mathrm{D})$ genes. Branches corresponding to partitions reproduced in less than $50 \%$ bootstrap replicates are collapsed. The percentage of replicate trees in which the associated taxa clustered together in the bootstrap test (1000 replicates) are shown next to the branches. Evolutionary distances were computed using the Tamura-Nei method and are in the units of the number of base substitutions per site. Rate variation among sites was modelled with a gamma distribution (shape parameter 0.71955, 1.54552, 1.67945 and 0.74334 , respectively). All positions containing gaps and missing data were eliminated from each dataset. Strain designations and accession numbers in bold type are from this study. 


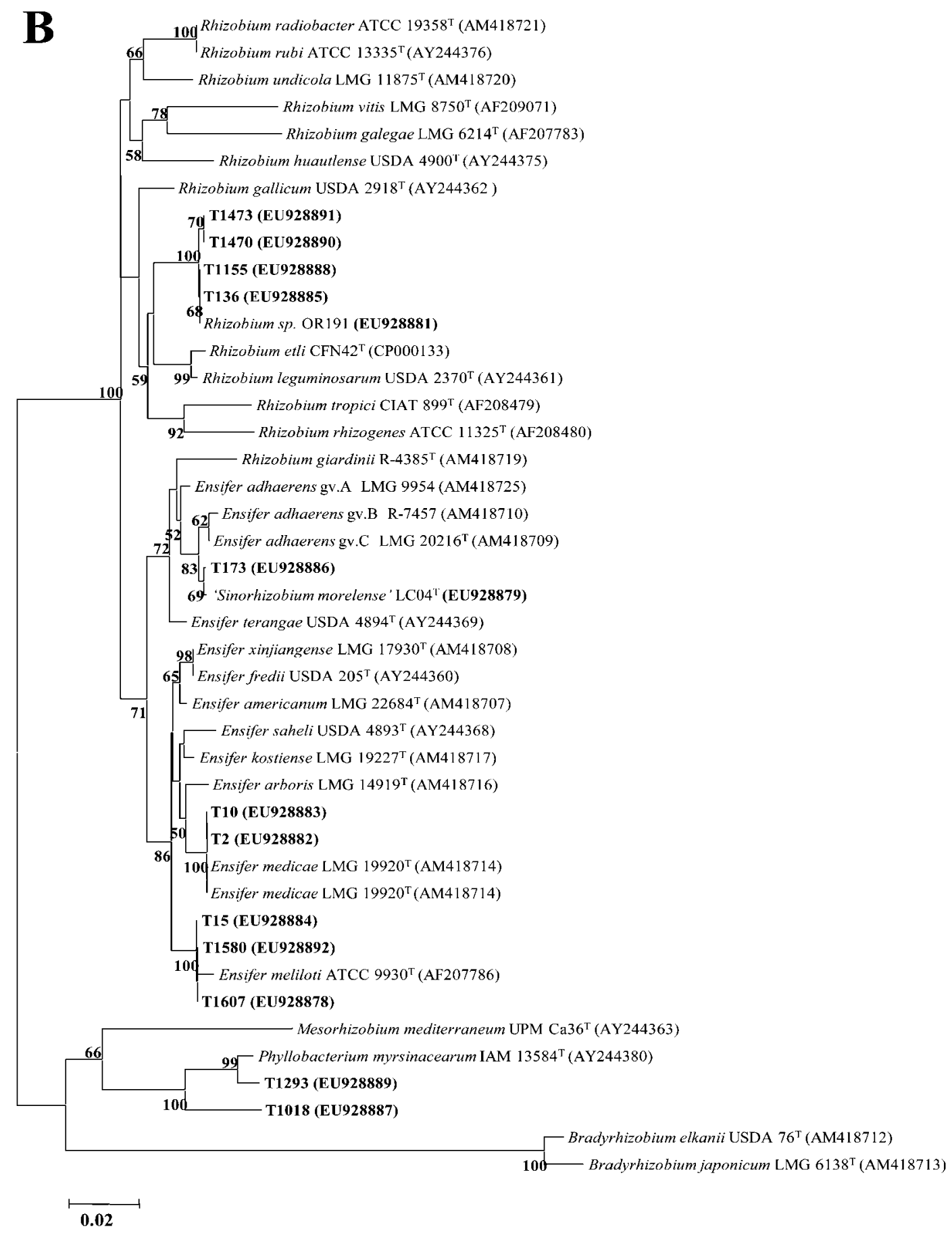

ISRm1, ISRm3, ISRm5, nodH and nodEFG divided the bacterial strains into nine distinct IS/nod genotypes, designated A through I. All reference strains had separate genotypes except for Rhizobium sp. OR191, which shared genotype B with strains T136 and T1155. Genomic DNAs from strains T1018 and T1293 (genotype I) did not hybridize with any of the IS or nod gene probes.

Hybridization profiles for nodH and nodEFG gene probes divided the test strains into six and nine symbiotic (nod) genotypes, respectively, whereas profiles for the three insertion sequence probes divided the strains into eight IS genotypes. Hybridization profiles are shown in Supplementary Fig. S1 (available with the online version of this paper).

\section{Analysis of nucleotide sequences}

Phylogenetic trees reconstructed from sequences of ribosomal (16S and 23Sr RNA) and protein-encoding ( $a t p D$ 


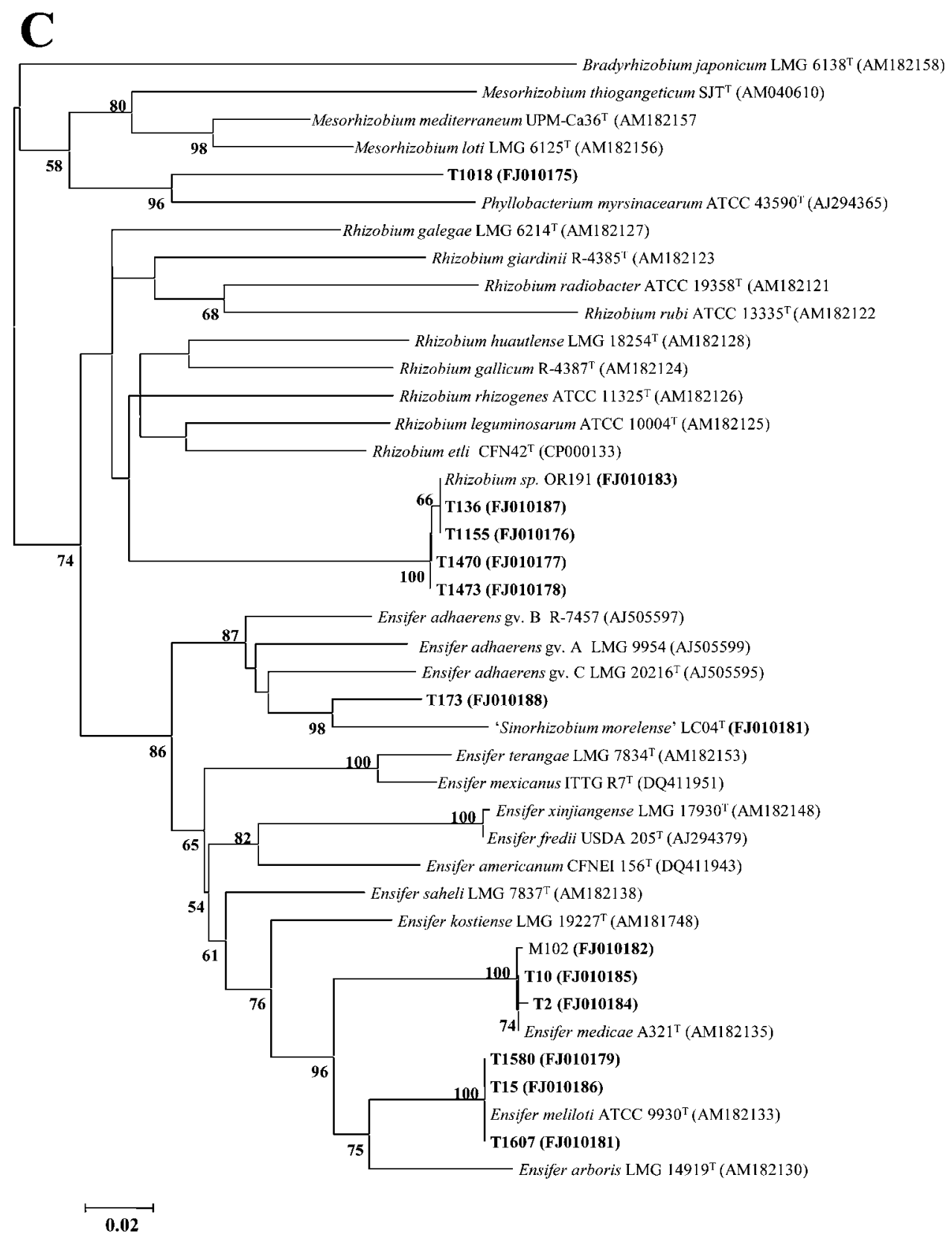

and $\operatorname{rec} A$ ) genes (Fig. 1), grouped representative bacterial strains with E. meliloti, E. medicae, 'S. morelense' and Ensifer adhaerans and with the genera Phyllobacterium and Rhizobium.

Based on sequences of $16 \mathrm{~S}$ rRNA (Fig. 1A), phage-resistant strain T173, the sole representative of genotype C, grouped with 'S. morelense' ( $99 \%$ sequence identity) with strong bootstrap support of $95 \%$.

Phage-resistant strains T1470 and T1473 (genotype A) and T136 and T1150 (genotype B) had identical 16S rRNA sequences to Rhizobium sp. OR191. The cluster formed by strains of Rhizobium sp. was separate from the closest relative (Rhizobium etli CFN42 ${ }^{\mathrm{T}}$ ).
BLASTN searches indicated that several bacterial strains isolated from different regions of the world have high $16 \mathrm{~S}$ rRNA sequence similarity to reference strain OR191and related strains. Notable examples include strain $\mathrm{HB} 8 \mathrm{cl}$ (GenBank accession no. DQ280489) isolated from a root nodule of Phaseolus vulgaris in France, strain UMR 7370 isolated from Dalea purpurea in the USA (GenBank accession no. EF107507), and strains SEMIA 6436, SEMIA 6437 and SEMIA 6438 (GenBank accession nos FJ025119, FJ 025118 and FJ025120, respectively), which are used in inoculants for tropical legumes such as Adesmia latifolia and Acaciella angustissima in Brazil. As expected, these strains grouped closely with Rhizobium sp. OR191 


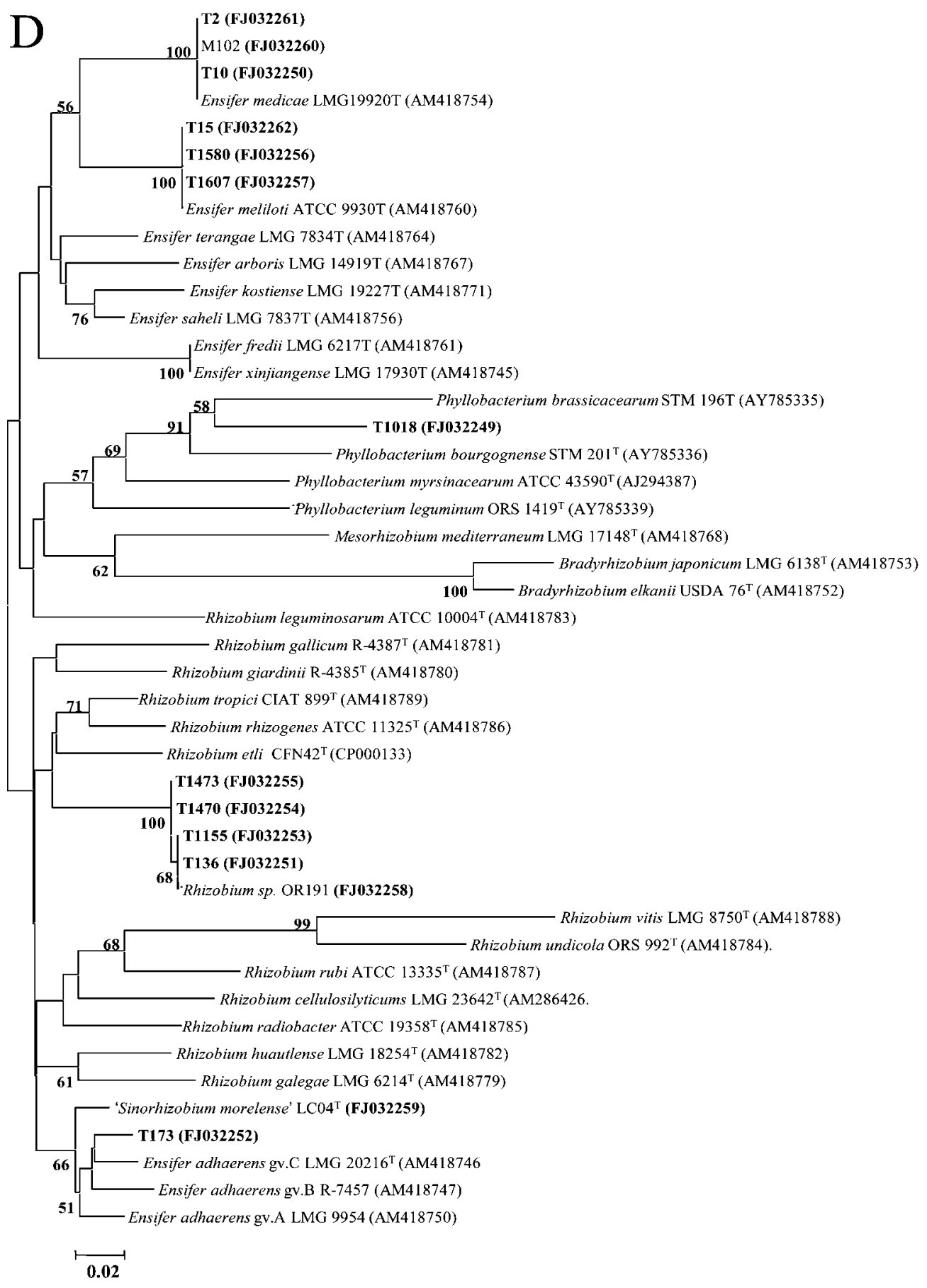

and with strains, T1470, T1473, T136 and T1150 when they were included in the 16S rRNA gene tree (not shown).

Phage-resistant strains T1018 and T1293 (genotype I), were placed in the genus Phyllobacterium (Fig. 1A). Strain T1018 represented a distinct lineage within the Phyllobacterium group with bootstrap support of $74 \%$. Strain T1293 was distinct from, but clustered with, $P$. brassicacearum and $P$. myrsinacearum with relatively low $(<70 \%)$ bootstrap support.

Phage-resistant strains, T15, T1580 and T1607 (genotypes F, G and $\mathrm{H}$, respectively) clustered with E. meliloti whereas phage-susceptible strains T2 (PT24; genotype D) and T10 (PT13; genotype E), clustered with E. medicae $\mathrm{A} 321^{\mathrm{T}}$ and reference strain M102.

The grouping of our bacterial strains in the tree inferred from sequences of $16 \mathrm{~S}$ rRNA (Fig. 1A) was generally consistent with the grouping in trees based on sequences of $23 \mathrm{~S}$ rRNA, recA and atpD genes (Figs $1 \mathrm{~B}, \mathrm{C}$ and $\mathrm{D}$, respectively).

An exception was the relative placement of strain T173 in the tree inferred from atpD sequences; bootstrap support for the placement of T173 as a neighbour of E. adhaerans 
genomovar (gv.) C was low ( $\leqslant 50 \%$ ). Strain T173 was also differentiated from ' $S$. morelense' in the gene tree inferred from $\mathrm{rec} A$ sequences (bootstrap support, $98 \%$ ).

In trees inferred from $23 \mathrm{~S}$ rRNA, recA and atpD sequences, bacteria comprising Rhizobium sp. were placed in two subgroups: one consisting of T136, T1155 and reference strain OR191 and the other consisting of strains T1470 and T1473. These two subgroups correspond to Rhizobium sp. genotypes A and B defined by Southern hybridization.

E. medicae strain T2 (genotype D) and T10 (genotype E) were differentiated only in the recA gene tree topology (Fig. 1C).

BLASTN searches revealed that Ensifer sp. strain T173 is highly similar to non-symbiotic Ensifer sp. strain LMG 20571 isolated from Belgian soil in that maximum sequence identity is $100 \%$ for $16 \mathrm{~S}$ rRNA, 23S rRNA, atpD and recA gene sequences (GenBank accession nos AJ420776, AM418718, AM418772 and AM182151, respectively). Phyllobacterium sp. strain T1018 is similar to nonsymbiotic strain CCBAU 13011 isolated in China, with a maximum sequence identity of $100 \%$ for $16 \mathrm{~S}$ rRNA, $99 \%$ for recA and $97 \%$ for atpD (GenBank accession nos EU170548, EU255214 and EU170569, respectively). Phylogenetic trees that included the respective nucleotide sequences for Ensifer sp. LMG 20571 and Phyllobacterium sp. CCBAU 13011 showed that the former strain grouped closely with Ensifer sp. T173 and that the latter strain grouped with Phyllobacterium sp. T1018 (not shown).

\section{Frequency}

Table 4 shows estimates of the frequency of occurrence of bacterial genotypes (defined by RFLP and Southern hybridization). Phage-resistant bacteria belonging to Rhizobium sp. genotype B predominated on alfalfa (frequency about $68 \%$ ), whereas from sweet clover, this genotype was recovered infrequently $(\sim 1 \%)$. In contrast, Rhizobium sp. genotype A was recovered only from alfalfa at low frequency $(\sim 1 \%)$.

Phage-resistant isolates of E. meliloti (genotypes F, G, H), Ensifer sp. (genotype C) and the two Phyllobacterium spp. (genotype I) were recovered from alfalfa and/or sweet clover at frequencies of $1 \%$ or less.

Phage-susceptible E. medicae isolates consisting of genotypes D and $\mathrm{E}$ were recovered from sweet clover and alfalfa at low frequency $(\sim<1-7 \%)$.

\section{Symbiotic characteristics}

Additional Southern analyses of genomic DNAs from Phyllobacterium sp. strains T1018 and T1293 (digested with EcoRI) revealed no hybridization with nifH and nodC gene probes, suggesting that these strains are non-symbiotic. Plant tests showed that neither strain elicited nodules on alfalfa, sweet clover or Medicago lupulina (black medic).

All strains comprising the genera Ensifer and Rhizobium nodulated alfalfa and sweet clover (Table 5a). E. melitoti strains T15, T1580 and T1607 were of moderate to high relative effectiveness (RE) with regard to nitrogen fixation in association with these two hosts.

E. medicae M102 was poorly effective on alfalfa $(\mathrm{RE}=13 \%)$ whereas strains $\mathrm{T} 2$ and $\mathrm{T} 10$ were highly effective on this host $(\mathrm{RE}=159 \%$ and $155 \%$, respectively). In association with sweet clover, strains T2, T10 and M102 were more effective than the standard strain of E. meliloti.

Ensifer sp. strain T173 elicited large numbers of small white nodules on roots of alfalfa and sweet clover but did not fix nitrogen $(\mathrm{RE}=-2.8 \%)$.

Strains representing Rhizobium sp. were moderately effective in association with alfalfa, with $\mathrm{RE}$ values of between $64 \%$ and $77 \%$. In contrast, reference strain OR191 was poorly effective. On sweet clover, all Rhizobium sp. isolates showed low levels of effectiveness.

Bacteria and reference strains representing E. meliloti, E. medicae and Ensifer sp. elicited a few small white nodulelike structures on roots of Phaseolus vulgaris (beans) that did not fix nitrogen (Table 5b). In contrast, bean plants inoculated with strains of Rhizobium sp. were well nodulated. However, these strains were of low to moderate effectiveness on this host, with RE values varying between $19 \%$ (strain T1470) and 78.1\% (strain OR191).

E. medicae strains T2 and T10 nodulated the annual legume Medicago polymorpha and were effective relative to standard strain M102 and uninoculated control plants; RE values were $101 \%$ (T2) and $109 \%$ (T10). E. meliloti ATCC $9930^{\mathrm{T}}$ did not elicit nodules on Med. polymorpha (data not shown).

The host range of Ensifer sp. strain T173 was further examined to determine whether this bacterium is capable of fixing nitrogen with a legume host. The following additional plant hosts were tested: Medicago lupulina, Medicago laciniata, Trigonella foenum-graecum, Trifolium repens, Lotus corniculatus, Lotus pedunculatus, Vicia sativa, Vicia cracca, Onobrychis vicifolia, Macroptilium atropurpureum 'Siratro', Lupinus nootkatensis, Leucaena leucocephala, Lathyrus sativus, Pisum sativum, Glycine max and Vigna unguiculata. Of these plant hosts, strain T173 elicited small white nodules on roots of all 10 replicate plants of $\mathrm{Med}$. lupulina and Macroptilium atropurpureum 'Siratro', but did not fix nitrogen.

\section{Plasmid analysis}

Data for plasmids and Southern hybridization with nifH and nodC gene probes are given in Table 6; examples are shown in Fig. 2. Bacterial strains possessed between two and four plasmids and had distinct plasmid profiles, except for reference strain OR191, which shared an identical profile with strains of Rhizobium sp. belonging to genotype B. 
Table 5. Symbiotic characteristics

Effective standard strains were E. meliloti ATCC $9930^{\mathrm{T}}$ for Med. sativa and Mel. alba, and R. etli CFN42 ${ }^{\mathrm{T}}$ for P. vulgaris. Values are means of five replicates (two plants per replicate) for each inoculation treatment and host species combination; uninoculated plants were without nodules. RE, relative effectiveness; SED, standard error of difference between means. Letters in parentheses represent IS/nod genotypes (see Table 4).

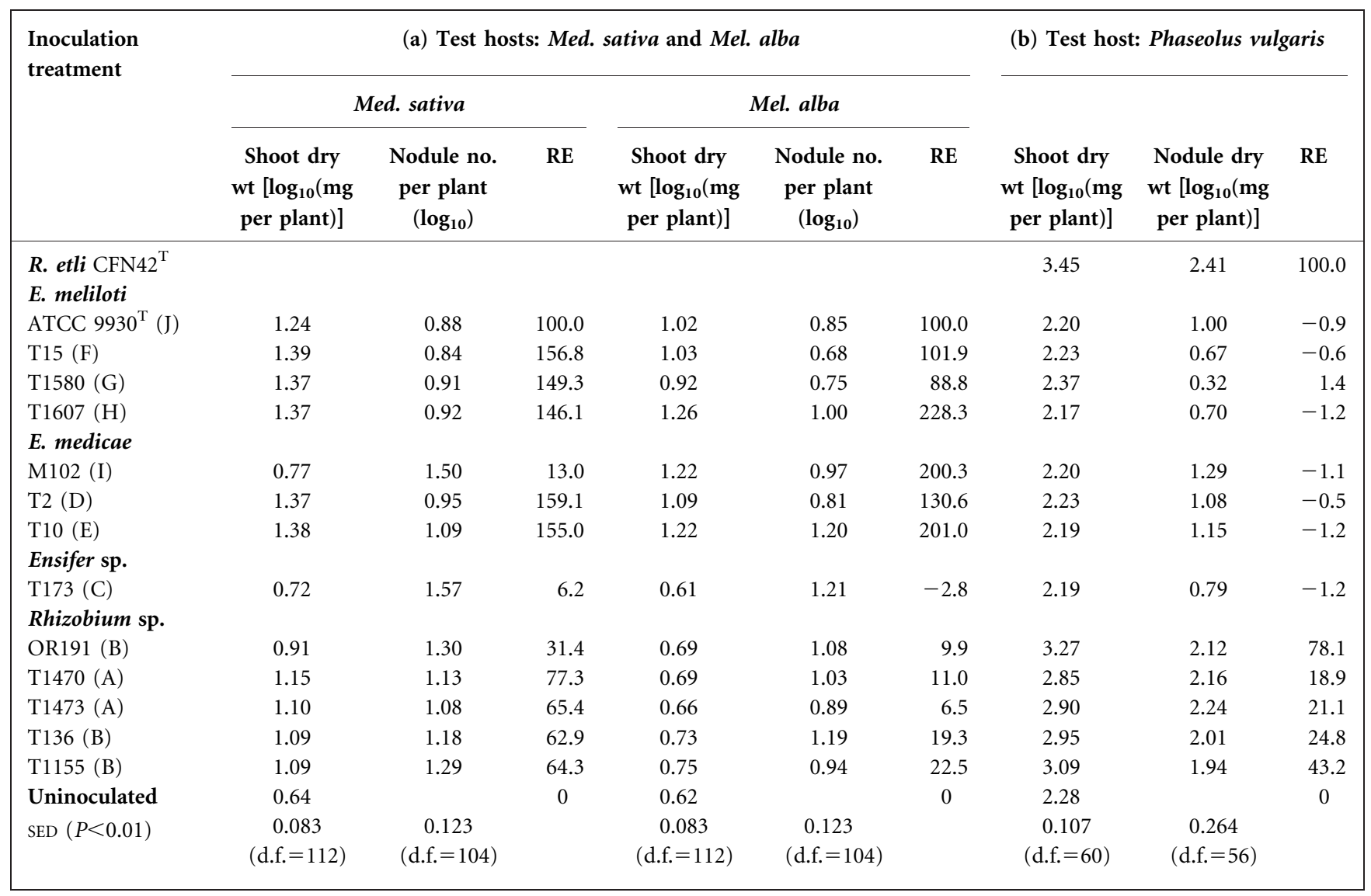

${ }^{\star}$ Effective standard strains.

Strains of E. meliloti, E. medicae, Ensifer sp. and Phyllobacterium sp. possessed plasmid bands with mobilities in agarose gels less than or equivalent to the megaplasmid band of the reference strain, E. meliloti SU47.

Only strains representing E. meliloti and E. medicae had megaplasmid bands in agarose gels that hybridized to nifH and nodC gene probes (i.e. symbiotic megaplasmids or pSymA). E. medicae strain T10 possessed a pSymA as well as a $170 \mathrm{~kb}$ plasmid that hybridized to nifH, but not to nodC gene sequences.

Ensifer sp. strain T173 was unusual in that it had a nonsymbiotic megaplasmid as well as a $175 \mathrm{~kb}$ symbiotic plasmid.

All Rhizobium sp. strains possessed a relatively large symbiotic plasmid that was only slightly smaller in size (i.e. had greater mobility in agarose gels) than the reference megaplasmid band of E. meliloti SU47 (Fig. 2).

\section{Acid production and antibiotic resistance}

All strains produced an acidic reaction in mineral salts agar medium containing mannitol (Table 6). Phyllobacterium sp. produced the most acid ( $\mathrm{pH}$ range 4.5-4.7), E. meliloti and $E$. medicae were intermediate ( $\mathrm{pH}$ range $5.4-5.7)$, whereas Rhizobium sp. produced a slightly acid to nearneutral reaction ( $\mathrm{pH}$ range 6.4-6.7).

Ensifer sp. T173 and 'S. morelense' $\mathrm{Lc}^{\mathrm{T}} 4^{\mathrm{T}}$ differed from strains of E. meliloti and E. medicae in that they showed relatively high levels of resistance to carbenicillin $\left(>1000 \mu \mathrm{g} \mathrm{ml}^{-1}\right)$, kanamycin $\left(100-500 \mu \mathrm{g} \mathrm{ml}^{-1}\right)$ and neomycin (100 $\mu \mathrm{g} \mathrm{ml}^{-1}$ ) (Table 6). Phyllobacterium sp. strains T1018 and T1293 also showed relatively high levels of resistance to carbenicillin and kanamycin. Strain T1293 was unusual in that it showed a high level of resistance $\left(>50 \mu \mathrm{g} \mathrm{ml}^{-1}\right)$ to tetracycline. E. medicae T2, T10 and reference strain M102 differed in their levels of resistance to carbenicillin. 
Table 6. Plasmids, acid production and antibiotic resistance

\begin{tabular}{|c|c|c|c|c|c|c|c|c|c|c|}
\hline \multirow[t]{2}{*}{ Bacterial strain ${ }^{\star}$} & \multirow{2}{*}{$\begin{array}{l}\text { IS/nod } \\
\text { genotype }\end{array}$} & \multirow{2}{*}{$\begin{array}{c}\text { Plasmid } \\
\text { configuration } \dagger\end{array}$} & \multirow{2}{*}{$\begin{array}{l}\text { Acid production } \\
\qquad(\mathrm{pH}) \ddagger\end{array}$} & \multicolumn{7}{|c|}{ Antibiotic resistance $\left(\mu \mathrm{g} \mathrm{ml}^{-1}\right) \S$} \\
\hline & & & & Car & Kan & Ery & Neo & Gen & Tet & Nal \\
\hline \multicolumn{11}{|l|}{ E.meliloti } \\
\hline ATCC $9930^{\mathrm{T}}$ & $\mathrm{J}$ & M, 180 & 5.44 & ND & & & & & & \\
\hline $\mathrm{T} 15$ & $\mathrm{~F}$ & M, 220, 190, 45 & 5.60 & 50 & 5 & 50 & $<5$ & 5 & $<5$ & $>20$ \\
\hline $\mathrm{T} 1580$ & G & M, 100 & 5.61 & $>50$ & $>5$ & 100 & $>5$ & $>5$ & $<5$ & $>20$ \\
\hline T1607 & $\mathrm{H}$ & M, $200,170,150$ & NT & 100 & $>5$ & 100 & $>5$ & $>5$ & $<5$ & $>20$ \\
\hline \multicolumn{11}{|l|}{ E. medicae } \\
\hline M102 & $\mathrm{K}$ & M, 300 & 5.63 & 50 & $<5$ & 100 & $<5$ & $>5$ & $>5$ & $>20$ \\
\hline $\mathrm{T} 2$ & $\mathrm{D}$ & M, 300, 160 & 5.67 & $>100$ & $<5$ & 100 & 5 & $>5$ & $<5$ & $>20$ \\
\hline $\mathrm{T} 10$ & $\mathrm{E}$ & M, 170\# & 5.41 & $<5$ & $<5$ & 100 & $<5$ & $>5$ & $<5$ & $>20$ \\
\hline \multicolumn{11}{|l|}{ 'S. morelense' } \\
\hline $\mathrm{Lc} 04^{\mathrm{T}}$ & ND & $>1000,670,540 \|$ & ND & $>1000$ & 500 & 100 & 100 & 5 & $<5$ & 20 \\
\hline \multicolumn{11}{|l|}{ Ensifer sp. } \\
\hline $\mathrm{T} 173$ & $\mathrm{C}$ & $M,>400,>400,175$ & 5.75 & $>1000$ & $>100$ & 100 & 100 & $<5$ & $<5$ & 20 \\
\hline \multicolumn{11}{|l|}{ Rhizobium sp. } \\
\hline OR191 & $\mathrm{B}$ & $\mathrm{C},<\mathbf{M}, 140$ & 6.74 & $>50$ & 5 & 5 & $<5$ & $<5$ & $<5$ & $>20$ \\
\hline T136 & $\mathrm{B}$ & $\mathrm{C},<\mathbf{M}, 140$ & 6.60 & 100 & 5 & 5 & $<5$ & $<5$ & $<5$ & $>20$ \\
\hline T1155 & $\mathrm{B}$ & $\mathrm{C},<\mathbf{M}, 140$ & 6.77 & 100 & 5 & 5 & $<5$ & $<5$ & $<5$ & $>20$ \\
\hline $\mathrm{T} 1470$ & A & $\mathrm{C},<\mathbf{M}, 280,120$ & 6.44 & 100 & 5 & 5 & $<5$ & $<5$ & $<5$ & $>20$ \\
\hline $\mathrm{T} 1473$ & $\mathrm{~A}$ & $\mathrm{C},<\mathbf{M}, 280,140,120$ & 6.48 & 100 & 5 & 5 & $<5$ & $<5$ & $<5$ & $>20$ \\
\hline \multicolumn{11}{|c|}{ Phyllobacterium sp. } \\
\hline T1018 & I & $\geqslant M, 220,180$ & 4.65 & $>1000$ & 100 & 100 & 5 & $<5$ & $<5$ & $>20$ \\
\hline T1293 & I & $\geqslant \mathrm{M}, 280,260,180$ & 4.45 & $>1000$ & $>100$ & 100 & 50 & 5 & $>50$ & $>20$ \\
\hline
\end{tabular}

${ }^{\star}$ E. meliloti ATCC $9930^{\mathrm{T}}$, E. medicae M102, 'S. morelense' Lc04 ${ }^{\mathrm{T}}$ and Rhizobium sp. OR191 are reference strains.

$\dagger$ Plasmid sizes $(\mathrm{kb})$ estimated from comparisons to reference plasmids $(410,270,180$ and $55 \mathrm{~kb})$ in R. radiobacter PD67. C denotes band with mobility corresponding to the chromosomal band of PD67 or with mobility less than the reference megaplasmid band of E. meliloti SU47. M denotes band with mobility corresponding to the megaplasmid band of SU47. Plasmids in bold hybridized to nodC and nifH gene probes, with the exception of the $170 \mathrm{~kb}$ plasmid (designated \#), which hybridized only to $\mathrm{nifH}$.

$\ddagger$ Values are means of five replicates. Mean value for uninoculated control $=\mathrm{pH} 7.1 . \mathrm{SED}=0.044$ (d.f. $=56$ ).

§ar, carbenicillin; Kan, kanamycin; Ery, erythromycin; Neo, neomycin; Gen, gentamicin; Tet, tetracycline; Nal, nalidixic acid. Values (based on duplicates) represent the highest antibiotic concentration at which bacterial growth was inhibited relative to plates without antibiotic. ND, Not determined.

IIPlasmid data from Wang et al. (1999).

Strains of Rhizobium sp. showed a similar spectrum of resistance to reference strain OR191.

\section{DISCUSSION}

Bacteria related to Rhizobium sp. strain OR191 represent an anomalous group that were first isolated from nodules of alfalfa grown in acid soil in the United States and were reported to nodulate and fix nitrogen poorly in association with Phaseolus vulgaris (beans) and alfalfa (Eardly et al., 1992).

Our data indicate that Rhizobium sp. OR191 and related strains are unusual in that they produce a slightly acid to near neutral reaction in mineral salts agar medium containing mannitol, a characteristic that is more typical of the genus Bradyrhizobium (Bergey's Manual of Systematic Bacteriology, 2005). They are also unusual in that they possess a large symbiotic plasmid that is only slightly smaller than the pSymA and pSymB megaplasmids $(\sim 1300-1700 \mathrm{~kb})$ characteristic of E. meliloti (Barnett et al., 2001).

In the previous work (Bromfield et al., 2001), alfalfa and sweet clover were grown for two seasons in slightly acid field soil ( $\mathrm{pH}$ 6.1). Here, we show that the phage-resistant bacteria that were recovered at high frequency $(69 \%)$ from alfalfa consisted almost entirely of a single genotype (genotype B) that was indistinguishable from Rhizobium sp. strain OR191 by any of the genetic markers used or by plasmid profile analysis. The fact that isolates of genotype B were predominant on alfalfa but were recovered infrequently $(\sim 1 \%)$ from sweet clover probably reflects differential host plant selection of specific bacteria for symbiosis.

Del Papa et al. (1999) reported that infrequently occurring acid-tolerant bacteria isolated from alfalfa grown in acid 


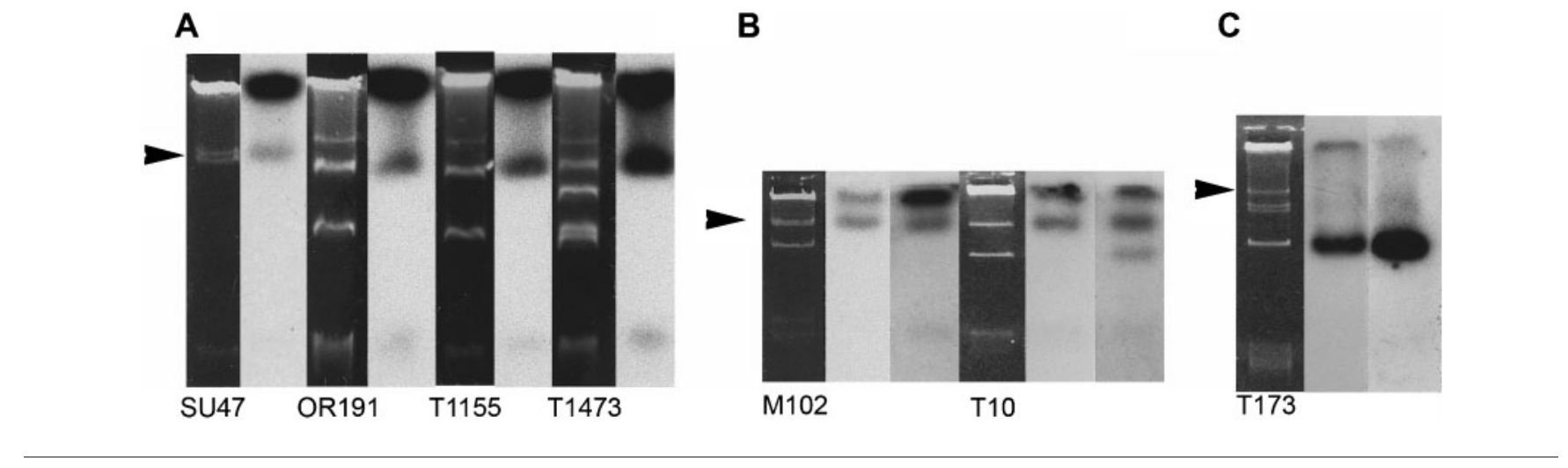

Fig. 2. Examples of variation in size and number of plasmids that hybridize to DNA probes for nodC and nifH among bacteria from Medicago sativa and Melilotus alba. Isolate designations are given below each respective agarose gel (left) and autoradiogram (right). E. meliloti SU47, E. medicae M102 and Rhizobium sp. OR191 are reference strains. Arrows indicate plasmids of mobility equivalent to that of the reference megaplasmid band in E. meliloti SU47. (A) Plasmids in E. meliloti SU47 and Rhizobium sp. OR191, T1155 and T1473 that hybridize to nodC. Identical hybridization profiles were obtained for the nifH gene probe (not shown). (B, C) Plasmids in E. medicae M102, T10 and Ensifer sp. T173 that hybridize to nodC and nifH, respectively. See Table 6 for estimated plasmid sizes.

soils in South America, were genetically homogeneous and closely related to Rhizobium sp. OR191. Our identification of a second bacterial genotype (genotype A) that occurred at low frequency $(\sim 1 \%)$ only from alfalfa, suggests that populations of OR191related bacteria need not necessarily be genetically homogeneous.

The isolation of OR191 related bacteria from nodules of Phaseolus grown in acid, copper-contaminated soil in France (Laguerre et al., 2006) indicates that their distribution is not restricted to acid soils in the Americas. Moreover, phylogenetic analysis of 16S rRNA sequences similar to strain OR191 revealed that related bacteria are associated with legumes such as Dalea purpurea in Minnesota (Mártir et al., 2007) and with Adesmia latifolia and Acaciella angustissima in Brazil (Binde et al., 2009), suggesting that these bacteria may be promiscuous with regard to their host range for symbiosis.

Our observation that OR191-related strains were more effective with regard to nitrogen fixation with alfalfa than with sweet clover might be indicative of their adaptation to symbiosis with alfalfa. Interestingly, our strains were less effective than OR191 in symbiotic association with Phaseolus vulgaris, perhaps reflecting the fact that OR191 originated in the United States, where beans have long been cultivated, whereas in eastern Canada this legume is rarely cultivated.

Competition for nodulation of the host legume by populations of rhizobia resident in soil represents a serious problem affecting the establishment of effective nitrogenfixing inoculant strains in crop ecosystems (e.g. Barran \& Bromfield, 1997). From a practical viewpoint, the extent to which soil populations of suboptimally effective Rhizobium sp. related to OR191 compete with effective introduced inoculant strains of E. meliloti for nodulation of alfalfa remains to be investigated.

Bacteria of the species 'S. morelense' are closely related to the predatory bacterial species, E. adhaerens. They are described as non-symbiotic (i.e. $\mathrm{Nod}^{-}$Nif ${ }^{-}$), highly resistant to various antibiotics and were first isolated from nodules of Leucaena leucocephala (Wang et al., 2002).

In this study, evidence was obtained that Ensifer sp. strain T173 (from sweet clover), is closely related to, but separate from, 'S. morelense' $\mathrm{LC} 04^{\mathrm{T}}$. Moreover, the data suggest that T173 belongs to the same genospecies as non-symbiotic Ensifer sp. strain LMG 20571 (Martens et al., 2007, 2008). However, strain T173 differs from both 'S. morelense' and Ensifer sp. LMG20571 by its ability to elicit ineffective nodules on alfalfa, sweet clover, black medic and Macroptilium atropurpureum and by the presence of a $175 \mathrm{~kb}$ symbiotic plasmid.

It is possible that strain T173 acquired its symbiotic plasmid via horizontal transfer (Broughton, 2003). In this connection, it is of interest to note that the in vitro introduction of a functional symbiotic plasmid to a strain of the non-symbiotic species E. adhaerans conferred on it the ability to nodulate certain legume hosts (Rogel et al., 2001).

While strain T173 did not fix nitrogen with any of a wide array of test legumes, it remains to be ascertained whether its symbiotic plasmid carries functional nif genes and is capable of conferring on this bacterium the ability to fix nitrogen in association with a legume host.

The fact that strain T173 was encountered only once among numerous bacterial isolates suggests either that it 
occurred infrequently in soil or that it is poorly competitive for nodulation of the plant host. Alternatively, root nodules occupied by T173 may have escaped sampling due to their small size. However, the fact that the similar, but non-symbiotic, strain LMG 20571 was isolated from soil in Belgium (Willems et al., 2003; Martens et al., 2007) suggests that T173-related bacteria may have a wide geographical distribution.

The finding that Phyllobacterium sp. strains T1018 and T1293 are non-symbiotic and were each recovered only once from nodules suggests that they may be opportunistic bacteria that occasionally occupy root nodules. Our data suggest that these strains may represent distinct genospecies within the genus Phyllobacterium. The fact that strain T1018 is related to the non-symbiotic strain CCBAU 13011, isolated from a root nodule of Vicia sp. in China (Lei et al., 2008), suggests that these bacteria may have a worldwide distribution.

Strains T1018 and T1293 were highly resistant to multiple antibiotics, in common with Ensifer sp. T173 in this study, and with 'S. morelense' described by Wang et al. (2002). In particular, strain T1293 was unusual in that it was highly resistant to the broad-spectrum antibiotic tetracycline. These Ensifer sp. and Phyllobacterium sp. strains originated from a site with no known history of antibiotic use (Bromfield et al., 2001). The ecological and biological significance of multiple antibiotic resistance in these naturally occurring bacteria remains to be ascertained.

The species E. medicae is closely related to E. meliloti, and represents a group of bacteria that nodulate and fix nitrogen in association with annual Medicago species (e.g. Med. polymorpha) that are native to Africa, Asia and the Mediterranean region (Rome et al., 1996).

Silva et al. (2007) obtained several isolates of E. medicae from naturalized Med. polymorpha, Med. lupulina and cultivated alfalfa in Mexico. These isolates may have originated from a single clone because they had identical plasmid profiles and were genetically homogeneous for all genetic markers analysed.

In contrast, we identified two distinct genotypes of $E$. medicae among phage-susceptible isolates from alfalfa and sweet clover. These two genotypes, represented by strains $\mathrm{T} 2$ and T10 respectively, were also differentiated on the basis of distinctive plasmid profiles. While these genotypes were minority components of the bacterial population inhabiting nodules, both were recovered at significantly higher frequency from sweet clover than from alfalfa, perhaps reflecting differential selection by the plant host.

It is of interest to note that strain T10 not only possessed a symbiotic megaplasmid (pSymA), but also a $170 \mathrm{~kb}$ plasmid carrying reiterated sequences of the nifH gene. It is possible that the $170 \mathrm{~kb}$ plasmid was acquired from another rhizobial species (Broughton, 2003). Alternatively, the reiterated nifH sequences may have originated from the pSymA of $E$. medicae via recombination (Rastogi et al., 1992).
The annual legume Med. lupulina (black medic) was observed to occur sporadically in the vicinity of the experimental site (Bromfield et al., 2001). It is possible that this legume served as a source of the E. medicae that were recovered from nodules of alfalfa and sweet clover plants grown in the field plots.

Our E. medicae strains were highly effective with regard to nitrogen fixation on alfalfa, sweet clover and Med. polymorpha, whereas strain M102 isolated from Medicago trunculata in Syria (Eardly et al., 1990) was poorly effective on alfalfa but effective on the other plant hosts. Although more comparisons are needed, it is tempting to suggest that the high level of effectiveness of our strains on alfalfa and sweet clover might reflect adaptation to symbiosis with naturalized species of Medicago (Med. sativa, Med. lupulina) and Melilotus (Mel. alba, Mel. officinalis) that are widespread in eastern Canada. In this regard, further study of the agricultural potential of Canadian E. medicae for alfalfa inoculation may be warranted.

The bacteria that were identified as E. meliloti constituted a minority of phage-resistant bacteria from alfalfa and sweet clover. Their low frequency was expected a priori because the typing phages were developed using E. meliloti strains as hosts (Bromfield et al., 2001) and because earlier studies showed that an overwhelming majority of bacterial isolates from Medicago and Melilotus species grown in Canadian soils are susceptible to these phages (e.g. Thurman \& Bromfield, 1988). The isolates identified as E. meliloti were divided into three genotypes. This heterogeneity is in line with earlier reports of moderate levels of genetic diversity in naturalized populations of E. meliloti in eastern Canada (e.g. Bromfield et al., 1998).

This study has provided new insights into the species diversity and characteristics of bacteria that occupy nodules of alfalfa and sweet clover. Diverse bacterial genotypes representing Ensifer sp., Phyllobacterium sp., Rhizobium sp., E. meliloti and E. medicae were identified among phageresistant and -susceptible bacterial isolates from these two legume species grown at a site with no known history of cultivation. It is remarkable that this wide bacterial diversity was encountered at a site, where initially bacteria able to nodulate alfalfa and sweet clover were not detected in soil (Bromfield et al., 2001).

We conclude that these diverse bacterial species were originally present in soil, although the possibility cannot be ruled out that they were introduced via transcontinental airborne dust, or on seed. Further study is needed to elucidate their origin and dispersal.

\section{REFERENCES}

Barnett, M. J., Fisher, R. F., Jones, T., Komp, C., Abola, A. P., BarloyHubler, F., Bowser, L., Capela, D., Galibert, F. \& other authors (2001). Nucleotide sequence and predicted functions of the entire Sinorhizobium meliloti pSymA megaplasmid. Proc Natl Acad Sci U S A 98, 9883-9888. 
Barran, L. R. \& Bromfield, E. S. P. (1997). Competition among rhizobia for nodulation of legumes. In Biotechnology and Improvement of Forage Legumes, pp. 343-374. Edited by B. D. McKersie \& D. C. W. Brown. New York: CAB International.

Barran, L. R., Bromfield, E. S. P., Rastogi, V., Whitwill, S. T. \& Wheatcroft, R. (1991). Transposition and copy number of insertion sequence ISRml are not correlated with symbiotic performance of Rhizobium meliloti from two field sites. Can J Microbiol 37, 576-579.

Barran, L. R., Bromfield, E. S. P., Laberge, S. \& Wheatcroft, R. (1994). Insertion sequence (IS) hybridization supports classification of $R$. meliloti by phage typing. Mol Ecol 3, 267-270.

Bergey's Manual of Systematic Bacteriology (2005). The Proteobacteria. Volume Two. Edited by J. Brenner, N. R. Kreig \& J. T. Staley. New York: Springer.

Binde, D. R., Menna, P., Bangel, E. V., Barcellos, F. G. \& Hungria, M. (2009). rep-PCR fingerprinting and taxonomy based on the sequencing of the 16S rRNA gene of 54 elite commercial rhizobial strains. Appl Microbiol Biotechnol 83, 897-908.

Bromfield, E. S. P., Thurman, N. P., Whitwill, S. T. \& Barran, L. R. (1987). Plasmids and symbiotic effectiveness of representative phage types from two indigenous populations of Rhizobium meliloti. J Gen Microbiol 133, 3457-3466.

Bromfield, E. S. P., Wheatcroft, R. \& Barran, L. R. (1994). Medium for direct isolation of Rhizobium meliloti from soils. Soil Biol Biochem 26, 423-428.

Bromfield, E. S. P., Behara, A. M. P., Singh, R. S. \& Barran, L. R. (1998). Genetic variation in local populations of Sinorhizobium meliloti. Soil Biol Biochem 30, 1707-1716.

Bromfield, E. S. P., Butler, G. \& Barran, L. R. (2001). Temporal effects on the composition of a population of Sinorhizobium meliloti associated with Medicago sativa and Melilotus alba. Can J Microbiol 47, 567-573.

Broughton, W. J. (2003). Roses by other names: taxonomy of the Rhizobiaceae. J Bacteriol 185, 2975-2979.

Del Papa, M. F., Balague, L. J., Sowinski, S. C., Wegener, C., Segundo, E., Abarca, F. M., Toro, T., Niehaus, K., Puhler, A. \& other authors (1999). Isolation and characterization of alfalfa-nodulating rhizobia present in acidic soils of Central Argentina and Uruguay. Appl Environ Microbiol 65, 1420-1427.

Eardly, B. D., Materon, L. A., Smith, N. H., Johnson, D. A., Rumbaugh, M. D. \& Selander, R. K. (1990). Genetic structure of natural populations of the nitrogen-fixing bacterium Rhizobium meliloti. Appl Environ Microbiol 56, 187-194.

Eardly, B. D., Young, J. P. W. \& Selander, R. K. (1992). Phylogenetic position of Rhizobium sp. strain OR191, a symbiont of both Medicago sativa and Phaseolus vulgaris, based on partial sequences of the $16 \mathrm{~S}$ rRNA and nifH genes. Appl Environ Microbiol 58, 1809-1815.

Felsenstein, J. (1985). Confidence limits on phylogenies: an approach using the bootstrap. Evolution 39, 783-791.

Hunt, D. E., Klepac-Ceraj, V., Acinas, S. G., Gautier, C., Bertilsson, S. \& Polz, M. F. (2006). Evaluation of $23 \mathrm{~S}$ rRNA PCR primers for use in phylogenetic studies of bacterial diversity. Appl Environ Microbiol 72, 2221-2225.

Gaunt, M. W., Turner, S. L., Rigottier-Gois, L., Lloyd-Macgilp, S. A. \& Young, J. P. (2001). Phylogenies of atpD and recA support the small subunit rRNA-based classification of rhizobia. Int J Syst Evol Microbiol 51, 2037-2048.

Laguerre, G., Courde, L., Nouaïm, R., Lamy, I., Revellin, C., Breuil, M. \& Chaussod, R. (2006). Response of rhizobial populations to moderate copper stress applied to an agricultural soil. Microb Ecol 52, 426-435.
Lei, X., Wang, E. T., Chen, W. F., Sui, X. H. \& Chen, W. X. (2008). Diverse bacteria isolated from root nodules of wild Vicia species in temperate region of China. Arch Microbiol 190, 657-671.

Mantelin, S., Fisher-Le Saux, M., Zakhia, F., Bena, G., Bonneau, S., Jeder, H., de Lajudie, P. \& Cleyet-Marel, J. C. (2006). Emended description of the genus Phyllobacterium and description of four novel species associated with plant roots: Phyllobacterium bourgognense sp. nov., Phyllobacterium ifriqiyense sp. nov., Phyllobacterium leguminum sp. nov. and Phyllobacterium brassicacearum sp. nov. Int $J$ Syst Evol Microbiol 56, 827-839.

Martens, M., Delaere, M., Coopman, R., De Vos, P., Gillis, M. \& Willems, A. (2007). Multilocus sequence analysis of Ensifer and related species. Int J Syst Evol Microbiol 57, 489-503.

Martens, M., Dawyndt, P., Coopman, R., De Vos, P., Gillis, M. \& Willems, A. (2008). Advantages of multilocus sequence analysis for taxonomic studies: a case study using 10 housekeeping genes in the genus Ensifer (including former Sinorhizobium). Int J Syst Evol Microbiol 58, 200-214.

Mártir, M. C., Tlusty, B., van Berkum, P. \& Graham, P. H. (2007). The genetic diversity of rhizobia associated with Dalea purpurea Vent. in fragmented grasslands of west-central Minnesota. Can J Microbiol 53, 351-363.

Posada, D. (2006). ModelTest Server: a web-based tool for the statistical selection of models of nucleotide substitution online. Nucleic Acids Res 34, W700-W703.

Rastogi, V. K., Bromfield, E. S. P., Whitwill, S. T. \& Barran, L. R. (1992). A cryptic plasmid of indigenous Rhizobium meliloti possesses reiterated nodC and nifE genes and undergoes DNA rearrangement. Can J Microbiol 38, 563-568.

Rogel, M. A., Hernández-Lucas, I., Kuykendall, L. D., Balkwill, D. L. \& Martinez-Romero, E. (2001). Nitrogen-fixing nodules with Ensifer adhaerens harboring Rhizobium tropici symbiotic plasmids. Appl Environ Microbiol 67, 3264-3268.

Rome, S., Fernandez, M. P., Brunel, B., Normand, P. \& CleyetMarcel, J. C. (1996). Sinorhizobium medicae sp. nov isolated from annual Medicago spp. Int J Syst Bacteriol 46, 972-982.

Saitou, N. \& Nei, M. (1987). The neighbor-joining method: a new method for reconstructing phylogenetic trees. Mol Biol Evol 4, 406425.

Segovia, L., Young, J. P. W. \& Martinez-Romero, E. (1993). Reclassification of American Rhizobium leguminosarum biovar phaseoli typel strains as Rhizobium etli sp. nov. Int J Syst Bacteriol 43, 374-377.

Silva, C., Kan, F. L. \& Martinez-Romero, E. (2007). Population genetic structure of Sinorhizobium meliloti and S. medicae isolated from nodules of Medicago spp. in Mexico. FEMS Microbiol Ecol 60, 477-489.

Tambong, J. T., de Cock, A. W., Tinker, N. A. \& Levesque, C. A. (2006). Oligonucleotide array for identification and detection of Pythium species. Appl Environ Microbiol 72, 2691-2706.

Tamura, K. \& Nei, M. (1993). Estimation of the number of nucleotide substitutions in the control region of mitochondrial DNA in humans and chimpanzees. Mol Biol Evol 10, 512-526.

Tamura, K., Dudley, J., Nei, M. \& Kumar, S. (2007). MEGA4: Molecular Evolutionary Genetics Analysis (MEGA) software version 4.0. Mol Biol Evol 24, 1596-1599.

Thurman, N. P. \& Bromfield, E. S. P. (1988). Effect of variation within and between Medicago and Melilotus species on the composition and dynamics of indigenous populations of Rhizobium meliloti. Soil Biol Biochem 20, 31-38.

van Berkum, P. \& Fuhrmann, J. J. (2000). Evolutionary relationships among the soybean bradyrhizobia reconstructed from 16S rRNA gene 
and internally transcribed spacer region divergence. Int J Syst Evol Microbiol 50, 2165-2172.

van Berkum, P., Terefework, Z., Paulin, L., Suomalainen, S., Lindström, K. \& Eardly, B. D. (2003). Discordant phylogenies within the rrn loci of rhizobia. J Bacteriol 185, 2988-2998.

Vinuesa, P., Silva, C., Werner, D. \& Martinez-Romero, E. (2005). Population genetics and phylogenetic inference in bacterial molecular systematics: the roles of migration and recombination in Bradyrhizobium species cohesion and delineation. Mol Phylogenet Evol 34, 29-54.

Wang, E. T., Martinez-Romero, J. \& Martinez-Romero, E. (1999). Genetic diversity of rhizobia from Leucaena leucocephala nodules in Mexican soils. Mol Ecol 8, 711-724.

Wang, E. T., Tan, Z. Y., Willems, A., Ferdandez-Lopez, M. \& MartinezRomero, E. (2002). Sinorhizobium morelense sp. nov., a Leucaena leucocephala- associated bacterium that is highly resistant to multiple antibiotics. Int J Syst Evol Microbiol 52, 1687-1693.

Willems, A., Fernandez-Lopez, M., Munoz-Adelantado, E., Goris, J., De Vos, P., Martinez-Romero, E., Toro, N. \& Gillis, M. (2003). Description of new Ensifer strains from nodules and proposal to transfer Ensifer adhaerans casida 1982 to Sinorhizobium as Sinorhizobium adhaerens comb. nov. request for an opinion. Int $J$ Syst Evol Microbiol 53, 1207-1217.

Young, J. M. (2003). The genus name Ensifer Casida 1982 takes priority over Sinorhizobium Chen et al. 1988, and Sinorhizobium morelense Wang et al. 2002 is a later synonym of Ensifer adhaerens Casida 1982. Is the combination 'Sinorhizobium adhaerens' (Casida 1982) Willems et al. 2003 legitimate? Request for an Opinion. Int J Syst Evol Microbiol 53, 2107-2110.

Edited by: H.-M. Fischer 